\title{
Beyond the Binary: Rethinking Gender Neutrality in Indian Rape Law
}

\author{
Harshad PATHAK* \\ National Law University - Delhi, India \\ harshadp9I@gmail.com
}

\begin{abstract}
Despite expanding the definition of rape under the Indian Penal Code to include nonpenile-vaginal acts of penetration, the said definition continues to conform to a gender-specific notion of rape, based on a predetermined characterization of the victim-perpetrator framework on the basis of their genders. Herein, I will critique this idea of gender specificity in Indian rape law on the grounds that it reinforces a binary notion of gender, and results in gross underinclusion. Instead, it is more appropriate to adopt a human-rights-based approach in defining the offence of rape, and negate the role of gender in identifying the victims and perpetrators of an act of rape. The argument is pillared on a state's obligation to not discriminate on the basis of sex, the recognition of transgender rights, and an assessment of the common grounds for opposing gender neutrality in Indian rape law.
\end{abstract}

"My name is John Kelly, and I'm a survivor of rape and intimate partner violence. I was raped twice while in college, but one of my experiences doesn't fit into traditional definitions of rape."

John Kelly was a student at Tufts University, who was raped by his former male partner. In 20 I 4, he became the first person to testify before the United States Congress on the issue of same-sex sexual violence. To dissipate the stigma surrounding the issue, John recounted his traumatic experience and testified to his school's inability to respond to his situation. In doing so, he not only highlighted the inherent sense of inertia in the legal discipline while dealing with sexuality, but also laid bare some glaring limitations of the traditional notion of rape.

The traditional notion of rape usually denotes a definition that requires the existence of penile-vaginal penetration. While its limitations are multiple, I intend to focus on

* $\quad$ BA, LLB (Hons) (National Law University - Delhi). The author is formerly an Associate in the Dispute Resolution practice at Luthra \& Luthra Law Offices in Delhi. In September 20I6, he will take part in the LLM in International Dispute Settlement (MIDS) programme, run by the Geneva University Law School and the Graduate Institute of International and Development Studies. I am grateful to Associate Professor Mrinal Satish at the National Law University, Delhi, for his guidance, and to my colleagues, Ms Divya Srinivasan and Mr Pratyush Panjwani, for their constant encouragement and willingness to discuss with me the arguments that I have attempted to engage with herein.

I. John KELLY, “I'm a Survivor of Rape and Intimate Partner Violence-And I'm a Man” TIME (2 July 20I4), online: TIME <http://time.com/295 I I96/male-rape-survivor >. 
something more preliminary. My concern with such a constrained definition of rape stems from the predetermined characterization of the victim-perpetrator framework based on a rigid fixation to the gendered, male-on-female paradigm. Therefore, by the traditional notion of rape, I only refer to an exclusive understanding of rape as an act of sexual assault carried out by a man on any part of the body of a woman using either his penis or any other object.

In India, instances of sexual assault which do not conform to the male-on-female paradigm occur far more frequently than one would imagine. While official statistics in this regard are hard to come by, prominent feminist scholars like Laxmi Murthy acknowledge that " $[\mathrm{m}]$ en too can be sexually assaulted - by men, as well as by women (in rare cases)" and that "[w]omen too are capable of perpetrating sexual assault on men". ${ }^{2}$ However, such understanding is not reflected in the framing of India's criminal laws. Though the definition of the offence of rape under Section 375 of the Indian Penal Code (IPC) has undergone several amendments since its inception in I 860, it continues to conform to the traditional notion of rape. Presently, Section 375 of the IPC provides that a man is said to commit rape upon a woman if he performs any of the enlisted actions on the woman's body under any of the seven circumstances described in the provision. ${ }^{3}$

Following the enactment of the Criminal Law (Amendment) Act, 20I3, the definition of rape is no longer restricted to cases of penile-vaginal penetration, but also includes the penetration of the vagina, mouth, urethra, anus, or any part of the body of a woman by a man using any object or part of his body. ${ }^{4}$ However, it remains gender specific. In other words, the IPC presupposes the victim of a rape to be a woman and the perpetrator to be a man, and does not view instances of sexual assault on the body of a male or a transgender person, or where the perpetrator is a female or a transgender person, as constituting an act of rape.

This impulse to view the rape narrative as exclusively that of a man violating a woman does an injustice to those whose own rape stories do not fit the typical mould that is easiest for us to understand. ${ }^{5}$ There is a growing need to reconsider the characterization of rape under the IPC in gender-specific terms, and to factor in the interests of various stakeholders which were not previously taken into consideration. As per research conducted by the Centre for Civil Society in 2013: "[o]ut of the 96 countries studied, 63 were found to have rape or sexual assault laws written in genderneutral language ... and 6 had partly gender-neutral laws (the perpetrator was defined as male and the victims could be male or female." ${ }^{6}$ It is this particular concern that I

\footnotetext{
2. Partners for Law in Development (PLD), "Comments by Laxmi Murthy to Criminal Law Amendment Bill 2000" at 3, online: PLD <http://pldindia.org/wp-content/uploads/2013/o4/Comments-by-LaxmiMurthy-to-Criminal-Law-Amendment-Bill-2000.pdf> [PLD, “Comments by Laxmi Murthy”].

3. Indian Penal Code, 1860 (India), s 375.

4. Criminal Law (Amendment) Act, 2013 (India), s 9.

5. John STOKES, “India's Law Should Recognize that Men Can Be Raped Too” Scroll.in (I I September 20I4), online: Scroll.in <http://scroll.in/article/6765 Io/India's-law-should-recognise-that-men-can-beraped-too $>$.

6. Jai VIPRA, “A Case for Gender Neutral Rape Laws in India” (2013) Centre for Civil Society Working Paper No 286 I at 7 .
} 
intend to address herein, albeit in the context of India. However, it is only the inadequacy, and not the constitutional permissibility, of a gender-specific definition of rape that I intend to critique. At the end of this exercise, I hope to be in a position to answer whether the offence of rape ought to be made gender-neutral from the perspectives of (i) the victim and (ii) the perpetrator, respectively.

In the first part, I will trace India's response to the question of gender neutrality in rape law. In the second part, I will attempt to characterize rape as a human rights violation, discarding the sympathy-driven construction that places more emphasis on the victim's societal honour and chastity. This characterization will form the tool with which, in the third part, I will assess the issue of gender neutrality in Indian rape law through the prism of human rights. Simultaneously, I will stress the need to alter a binary understanding of gender so as to incorporate the interests of the transgender community, especially after the judgment rendered by the Supreme Court of India in National Legal Services Authority $v$ Union of India (NALSA). ${ }^{7}$ Finally, in the fourth part, I will attempt to engage with some of the frequently raised arguments against gender neutrality in rape law, before summarizing my conclusions and suggestions.

\section{INDIA'S RESPONSE TO GENDER NEUTRALITY IN RAPE LAW}

India's response to gender neutrality in rape law can be described by two words: reactionary and inconsistent. Past judicial decisions and legislative amendments on the issue do not evidence any focused deliberation assessing the contours of the competing legal principles involved. There is little to suggest that the legislature considered the legitimate interests of all stakeholders while suggesting various amendments to the offence of rape under the IPC. ${ }^{8}$ As noted in the Minutes of the National Consultation Meeting organized in 200I in the aftermath of the $172^{\text {nd }}$ Report of the Law Commission of India, the opinions of various sexual minorities were never taken into consideration despite them emerging as a formidable force in the struggle for basic rights. ${ }^{9}$

The issue of gender neutrality in rape law was first raised in I 996 by Jaspal Singh, J of the Delhi High Court in Sudesh Jhaku v KC Jhaku. ${ }^{\text {Io }}$ Therein, the Court was required to determine whether the pre-20I 3 definition of rape could be interpreted to include non-penetrative sexual acts. However, the court went beyond its mandate to opine on the issue of gender neutrality as well. While holding that the prayed-for relief could not be granted by a judicial authority, but only by means of legislative amendment, Singh, J went on to articulate his preference for the offence of rape to be

7. National Legal Services Authority $v$ Union of India 20I4(5) SCALE I [NALSA].

8. Section 375 of the IPC has been amended by the Criminal Law (Amendment) Act, I983 (India), the Criminal Law (Amendment) Ordinance, 2013 (India), and finally the Criminal Law (Amendment) Act, 2013 (India). Though the Criminal Law (Amendment) Bill, 2012 (India) also sought to amend Section 375, the said Bill never came to be passed by the Parliament of India.

9. PLD, "Background to Discussions by Women's Groups on Sexual Assault Amendments (200I-2010)" (29 March 20IO) at I I, online: PLD <http://pldindia.org/wp-content/uploads/20I3/O4/Background-todiscussions-by-womens-groups-to-sexual-assault-amendments.pdf $>$.

Io. Sudesh Jhakuv K C Jhaku 1998 Cri LJ 2428. 
redefined in gender-neutral terms. ${ }^{\text {II }}$ The judge noted that the offence of rape was the sole avenue under the Indian criminal law for dealing with heinous acts of sexual assault before quoting the following passage from an article in the California Law Review:

Men who are sexually assaulted should have the same protection as female victims, and women who sexually assault men or other women should be as liable for conviction as conventional rapists. Considering rape as a sexual assault rather than as a special crime against women might do much to place rape law in a healthier perspective and to reduce the mythical elements that have tended to make rape laws a means of reinforcing the status of women as sexual possessions. ${ }^{\mathrm{I} 2}$

In I997, a Delhi-based group, Sakshi, filed a writ petition before the Supreme Court of India requesting it to reconsider the question that had arisen in Jhaku. In I999, the apex court framed the "precise issues" to be considered by the Law Commission of India. ${ }^{\mathrm{I} 3}$ Subsequently, the $I 72^{\text {nd }}$ Report of the Law Commission of India recommended that the offence of rape be substituted by a completely gender-neutral offence of "sexual assault". ${ }^{14}$ Interestingly, one of the key reasons for the Commission to make this suggestion was a sizeable increase in the number of instances of sexual assault against young boys that could not have been considered as acts of rape under the unamended definition. ${ }^{15}$ This concern, however, no longer holds much relevance after the Protection of Children from Sexual Offences Act, 2012 (POCSO), which aims to protect children from cases of sexual assault, harassment, and pornography when perpetrated by a man.

The recommendations of the Law Commission never translated into a legislative amendment up until 20I2, when the Criminal Law (Amendment) Bill, 2012 proposed a completely gender-neutral definition of rape. ${ }^{16}$ Many found this proposal to be surprising post POCSO since the reasons for the amendment remained unclear. The I $67^{\text {th }}$ Report on the 2012 Bill compiled by the Parliamentary Standing Committee does not disclose the factors considered by the Parliament before proposing a gender-neutral definition of rape. Per contra, it expressly acknowledges that the responses received from the public and State Governments favoured "[m]aking the offence of rape and sexual assault gender neutral only in so far as the victim is concerned, but making the perpetrator male. ${ }^{\mathrm{I} 7}$ Even the Note of Dissent given by two members of the Council of States described the adoption of a completely gender-neutral definition as trivializing the increasing number of rapes conducted by men on women. ${ }^{18}$ Amidst the prevailing ambiguity, this arcane proposal drew immense criticism from feminist scholars.

\footnotetext{
I I. Ibid at para 29.

I2. Camille E LEGRAND, "Rape and Rape Laws: Sexism in Society and the Law" (I973) 6I(3) California Law Review 919 at 94I (quoted in ibid at para 29).

I3. Sakshiv Union of India (I999) 6 SCC 59I [Sakshi].

I4. Law Commission of India, I72nd Report: Review of Rape Laws (New Delhi: Ministry of Law and Justice, Government of India, 2000) at para 7.2.

15. Ibid at para 3.I.

I6. Criminal Law (Amendment) Bill, 2012 (India), s 5.

17. Parliamentary Standing Committee, I67th Report on the Criminal Law (Amendment) Bill, 2012 (New Delhi: Rajya Sabha Secretariat, 2013) at 43.

I8. Ibid at $8 \mathrm{I}$.
} 
For instance, in her opening statement to the Justice Verma Committee (JVC), Ms Indira Jaising, a prominent Senior Advocate in India, labelled this move as unacceptable since rape was to be always characterized as a crime constitutive of patriarchy, and therefore, gendered. ${ }^{19}$

Before this 2012 Bill could be passed, the nation was rocked by the gang rape of a 23-year-old woman while travelling in a public bus in the capital city, Delhi, on I6 December 20I2. As a consequence of the outrage that followed, the legislature constituted the JVC to look into amending the criminal law in order to provide for quicker trials and enhanced punishment for committing sexual assaults of an extreme nature against women. ${ }^{20}$ Unlike the $20 \mathrm{I} 2 \mathrm{Bill}$, the JVC Report recommended that the offence of "rape" be retained, and not be substituted by the offence of "sexual assault", as it was widely understood as an expression of society's strong moral condemnation. ${ }^{2 I}$ The Committee also recommended that the offence be made gender neutral; however, this was to be done only from the perspective of the victim. While the JVC Report is admirably detailed, it does not contain an account of the reasons behind this recommendation.

Despite being well received, the recommendation of partial gender neutrality did not result in the desired change. In a rather perplexing reversal, the legislature promulgated the Criminal Law (Amendment) Ordinance, $2013^{22}$ to adopt a completely genderneutral definition of rape. This decision was criticized as being hurried, violative of the letter and spirit of the JVC Report, ${ }^{23}$ and bearing the potential to create a chilling effect on a woman's ability to file a rape complaint. ${ }^{24}$ Compelled by such criticism, and possibly motivated by political considerations, the legislature readjusted its stance after only a few months. In the next Parliamentary session, the legislature enacted the Criminal Law (Amendment) Act, 2013 to supplant the ordinance, and reverted to the gender-specific definition of rape that is presently in effect. ${ }^{25}$

While this move did appease those who had criticized the Ordinance, it also led to a new line of criticism from certain members of the queer ${ }^{26}$ movement, who viewed the reversion as damaging the interests of the transgender community. In the words of

I9. The Wilson Center, "Opening Statement by Additional Solicitor General Indira Jaising to the Verma Committee" The Wilson Center ( 15 October 2013), online: The Wilson Center <https://www. wilsoncenter.org/sites/default/files/IEvent $\%$ 20Summary $\%$ 2oand $\%$ 2oStatement $\%$ 2oby $\%$ 20Indira $\% 20$ Jaising \% 20to \% 20Verma \% 20Committee.pdf $>$.

20. See Justice Verma (Retd) Committee, Report of the Committee on Amendments to Criminal Law (New Delhi: Justice Verma (Retd) Committee, 20I3) [JVC, Report].

2I. Ibid at III, para 67.

22. Criminal Law (Amendment) Ordinance, 2013 (India), s 8.

23. “Activists Join Chorus Against Gender Neutral Rape Laws” The Times of India (7 March 20I3).

24. Nivedita MENON, “Gender Just, Gender Sensitive, Not Gender Neutral Rape Laws” Kafila (8 March 20I3), online: Kafila <http://kafila.org/20I3/o3/o8/gender-just-gender-sensitive-not-gender-neutralrape-laws/> [Menon, "Gender Just Laws”].

25. Criminal Law (Amendment) Act, 2013 (India), s 9.

26. I specifically use the word "queer", instead of an alternative reference, because it denotes whatever is at odds with the normal, the legitimate, and the dominant, and demarcates a positionality vis-à-vis the normative. See Arvind NARRAIN, "The Articulation of Rights Around Sexuality and Health: Subaltern Queer Cultures in India in the Era of Hindutva" (2004) 7(2) Health and Human Rights Journal I42 at I44-I 45 (quoting David M HALPERIN, Saint = Foucault: Towards a Gay Hagiography (Oxford and New York: Oxford University Press, I995) at 62). 
Arvind Narrain, "[t]he [2013 Act was] a slap in the face for all those who believed that finally transgender persons too are equal citizens in India". ${ }^{27} \mathrm{~A}$ gender-specific definition of the offence of rape worded in terms of men and women reflects a binary understanding of gender, creating doubts as to its suitability in the minds of gender equality proponents. The same is crucial considering that presently there is no offence under the IPC equivalent to the offence of rape that adequately protects the class of victims currently excluded. Pertinently, such criticism poses another difficult question - whether the interests of the transgender community ever featured in the entire discourse surrounding gender neutrality in Indian rape law.

A perusal of the above chronology clarifies that India's response to gender neutrality has been far from ideal. Despite a plethora of reports and amendments, the issue has yet to receive the purposive deliberation it warrants. The fact that most of the debate on the issue is confined to the corridors of various academic institutions and policy research organizations, as opposed to the Parliament or courts, is disappointing. As such, it is both reasonable and appropriate to address the issue of gender neutrality in Indian rape law afresh, at least from a theoretical standpoint.

\section{CHARACTERIZING RAPE}

An analysis of the issues of gender neutrality in rape law must be preceded by a study of the characterization of the offence of rape and its impact on the victim. As regards India, Section 375 of the IPC, as amended by the Criminal Law (Amendment) Act, $2013,{ }^{28}$ states that:

[a] man is said to commit rape if he-

(a) penetrates his penis, to any extent, into the vagina, mouth, urethra or anus of a woman or makes her to do so with him or any other person; or

(b) inserts, to any extent, any object or a part of the body, not being the penis, into the vagina, the urethra or anus of a woman or makes her to do so with him or any other person; or

(c) manipulates any part of the body of a woman so as to cause penetration into the vagina, urethra, anus or any part of body of such woman or makes her to do so with him or any other person; or

(d) applies his mouth to the vagina, anus, urethra of a woman or makes her to do so with him or any other person,

under the circumstances falling under any of the following seven descriptions .... ${ }^{29}$

The amended definition broadened the notion of rape to include non-penetrative sexual acts violating a woman's bodily integrity without any penile-vaginal penetration. The Criminal Law (Amendment) Act, 2013 achieved what the Supreme

\footnotetext{
27. “India's Progress on Rape Law Throws Transgender People Under the Bus" 429Magazine (22 April 20I3), online: 429Magazine <http://dot429.com/articles/I965-india-s-progress-on-rape-law-throwstransgender-people-under-the-bus $>$.

28. Criminal Law (Amendment) Act, 2013 (India), s 9.

29. Indian Penal Code, I860 (India), s 375 , as amended by ibid, s 9 .
} 
Court of India had refused to do in Sakshiv Union of India ${ }^{30}$ in 2004. In Sakshi, the apex court had held that when there is no ambiguity in the text of the provision, altering the definition of rape through judicial interpretation will "result in [a] good deal of chaos and confusion, and will not be in the interest of society at large." ${ }^{3}$ While this definition does define the ambit of the offence, one must travel beyond the statutory text to truly appreciate its import.

Unfortunately, judicial opinions on Indian rape law reflect a rather traditional understanding, where rape is not only viewed as an assault on the body of a woman, but also her modesty, chastity, and honour. This view stands on patriarchal bedrock, and undermines the sufficiency of arguments based on the victim's individual autonomy and bodily integrity. For instance, in I 980 Krishna Iyer, J opined in Rafiq $v$ State of $U P^{32}$ that:

[w] hen a woman is ravished [in rape,] what is inflicted is not merely physical injury, but "the deep sense of some deathless shame." ... [R]ape for a woman is deathless shame and must be dealt with as the gravest crime against human dignity. ${ }^{33}$

In I983, MP Thakkar, J elaborated on this idea in Bharwada Hirjibhaiv State of Gujarat, ${ }^{34}$ stating that when a woman is raped, she is likely to be ostracized by society, her own family, relatives, and friends, and that she would be overpowered by a feeling of shame on account of the upbringing in a tradition-bound society where by and large sex is taboo, amongst other social consequences evidencing of a loss of respect in society. ${ }^{35}$ Most recently, in State of MP $v$ Madanlal,,$^{36}$ the Supreme Court of India, while laudably dismissing the idea of a compromise in cases of rape or an attempt thereof, went on to reason that:

[rapes] are crimes against the body of a woman which is her own temple. These are offences which suffocate the breath of life and sully the reputation. And reputation, needless to emphasise, is the richest jewel one can conceive of in life. No one would allow it to be extinguished. When a human frame is defiled, the "purest treasure"[] is lost. Dignity of a woman is a part of her non-perishable and immortal self and no one should ever think of painting it in clay. There cannot be a compromise or settlement as it would be against her honour which matters the most. It is sacrosanct. ${ }^{37}$

Undeniably, this characterization of rape is a product of a property-based positioning of women in society, where their chastity constitutes a valuable treasure of importance..$^{38}$ At first, these observations may appear to hold little legal significance. However, continuous reliance on this property-based approach creates a distinction between an honourable victim of rape and a dishonourable one, who does not fulfil this criterion, the

30. Sakshiv Union of India AIR 2004 SC 3566.

3I. Ibid at para 22.

32. Rafiq $v$ State of UP (1980) 4 SCC 262.

33. Ibid at paras 6 and 9.

34. Bharwada Hiribhai v State of Gujarat (1983) 3 SCC 2 I 7.

35. Ibid at para Io.

36. State of MP $v$ Madanlal Criminal Appeal No 23 I of 2015.

37. Ibid at para 16 .

38. See Note, "Forcible and Statutory Rape: An Exploration of the Operation and Objectives of the Consent Standard" (I952) 62(I) Yale Law Journal 55 at 80. 
consequence being that, despite the prevalent evidentiary safeguards ${ }^{39}$ and judicial directions to this effect, ${ }^{\circ}$ while the testimony of the former is considered reliable, the latter's narration of an act of rape is often looked down on with suspicion.

Accordingly, instead of relying on the honour and chastity of a victim, a sounder alternative is to view an act of rape solely as a violation of the victim's bodily integrity; a simple denial of his or her sexual autonomy. This approach limits the possibility of non-factors like the victim's familiarity with sexual intercourse, moral character, etc. permeating into the trial. This is one of the reasons why this approach was also endorsed by the JVC Report, which noted that:

[r]ape is a form of sexual assault just like any other crime against the human body under the IPC .... It is [...] the offence against the bodily integrity of the woman as a person [and] it must not be viewed that a woman, while making a complaint, is in any way acting less honourably or in any way disturbing what is considered as the repository of honour of the family, community and others. ${ }^{4 \mathrm{I}}$

Conceptualizing rape only as a violation of the victim's bodily integrity lends ample support to its characterization as a human rights violation, and, accordingly, ensures that its adjudication is not contingent upon the victim's social positioning, but rather entitlement to his or her body. Though the Indian judiciary tends to fall back on the notion of honour to condemn an act of rape, it did endorse a more human-rights-based approach on two occasions. In 1996, in Bodhisatwa v Subhra Chakraborty, ${ }^{42}$ the Supreme Court of India opined that rape "is a crime against basic human rights and is also violative of the victim's most cherished of the Fundamental Rights, namely, the Right to Life contained in Article 2I." ${ }^{43}$ Subsequently, in Railway Board $v$ Chandrima Das, ${ }^{44}$ it emphasized that rape "is not a mere matter of violation of an ordinary right of a person but the violation of Fundamental Rights which is involved." ${ }^{45}$ However, such instances have been far too infrequent to reflect an institutional shift in the interpretation of the offence. Even the decisions in Bodhisatwa and Chandrima Das do not pertain to any criminal trial, but were rendered while determining the liability to compensate a rape victim. It is thus as unfortunate as it is surprising that the Indian judiciary, otherwise known for championing human rights, has been consistently silent in this regard when it comes to rape law.

Nonetheless, one may draw support from the manner in which instances of sexual harassment at work are viewed. In Vishaka $v$ State of Rajasthan, ${ }^{46}$ the Supreme Court of India noted that each incident of sexual harassment at the workplace results in a violation of the fundamental rights, including the right to life and liberty, protected by Article 2I of the Constitution of India (Constitution). ${ }^{47}$ The Preamble to

\footnotetext{
39. See, for instance, the Indian Evidence Act, 1872 (India), s I I4A.

40. See, for instance, State of Punjab v Gurmit Singh I996 (2) SCC 384: "The court must also ensure that cross-examination is not made a means of harassment or causing humiliation to the victim of crime".

4I. JVC, Report, supra note 20 at 83 , para 27 and 94, para 38.

42. Bodhisatwa $v$ Ms Subhra Chakraborty (I996) I SCC 490.

43. Ibid at para Io.

44. The Chairman, Railway Board v Mrs Chandrima Das (2000) 2 SCC 465 .

45. Ibid at para $\mathbf{I} 2$.

46. Vishaka $v$ State of Rajasthan (I997) 6 SCC 24I.

47. Ibid at para 3 .
} 
the Sexual Harassment of Women at Workplace (Prevention, Probibition and Redressal) Act, $2013^{48}$ also aptly recognizes that "the protection against sexual harassment ... [is a] universally recognised human right[]". ${ }^{49}$ Accordingly, it would be anomalous to recognize sexual harassment as a human rights violation, but treat an act of rape differently. ${ }^{50}$

Even internationally, it is an accepted practice to treat an act of rape as a form of violence, instead of a crime against community or societal honour. ${ }^{5 \text { I }}$ The UN Handbook for Legislation on Violence Against Women encourages countries to define sexual assault as a violation of bodily integrity and sexual autonomy. ${ }^{52}$ The Commentary to it condones the fact that "[s]exual violence has often been addressed in the problematic framework of morality, public decency and honour, and as a crime against the family or society, rather than a violation of an individual's bodily integrity. ${ }^{53}$ In fact, several human rights proponents support the idea that law reforms relating to sexual offences should be guided by states' obligations under international human rights law. ${ }^{54}$ In doing so, they place particular reliance on three international legal instruments, i.e. the Charter of the United Nations, the Universal Declaration of Human Rights (UDHR), and the International Covenant on Civil and Political Rights (ICCPR), all of which aim to "educate both officials and the general public in these norms, place governments failing to respect human rights on the defensive, and help create and legitimate internal and external pressures for human rights improvement." 55

In light of the above, the preference for an approach emphasizing the rights of rape victims, and not their social positioning, becomes obvious. Such rights include, inter alia, the right to life and dignity, and an assurance that these rights will be observed without discrimination on the basis of sex. Therefore, it is more appropriate to clarify the characterization of rape simply as a violation of the victims' bodily integrity and their right to life with dignity, ${ }^{56}$ instead of an act imposing a sense of deathless shame upon them due to an alleged loss of societal honour. In the Indian context, this would require the legislature to define the offence of rape in a responsible manner, and the judiciary to not let their interpretation be swayed by patriarchal conceptions.

48. Sexual Harassment of Women at Workplace (Prevention, Probibition and Redressal) Act, 20I3 (India).

49. Ibid at Preamble.

50. While the gender specificity of the Sexual Harassment Act, 2013 can be questioned on the grounds put forth herein, the same involves a consideration of additional contextual factors that are beyond the scope of this paper.

5I. Alice MILLER, "Sexuality, Violence Against Women and Human Rights: Women Make Demands and Ladies Get Protection" (2004) 7(2) Health and Human Rights Journal I6 at 2 I.

52. UN DESA, Handbook for Legislation on Violence Against Women (New York: UN Division for the Advancement of Women, 2010) at 26.

53. Ibid at 26.

54. Simon BRONIT and Ashutosh MISRA, "Reforming Sexual Offences in India: Lessons in Human Rights and Comparative Law" (20I4) 2(I) Griffith Asia Quarterly 37 at 5 I.

55. Richard B BILDER, "Rethinking International Human Rights: Some Basic Questions" (I969) I Wisconsin Law Review I7I at 205.

56. Constitution of India, art 2 I [Indian Constitution]. 


\section{THE ARGUMENT FOR GENDER NEUTRALITY}

It is accepted that:

[h] uman rights as a practice and doctrine needs to consider the basis on which the state regulates sexuality through law, especially criminal law .... Although sexual norms and attitudes have changed significantly in many countries over the last century, law is often slow to register these changes; sex law itself is notoriously resistant to change. ${ }^{57}$

In India, in the aftermath of the 16 December gang rape incident, the JVC Report suggested widespread reforms in the criminal law. These recommendations were based on a fundamental insistence that the right to be protected from sexual assault is guaranteed by the Constitution, and is one of the pillars on which the construct of gender justice stands. ${ }^{5}$ This assertion was made to emphasize two aspects: the first being that under India's constitutional framework women are equally entitled to the fundamental rights enshrined in Part III of the Constitution; and the second being that the state has a fundamental duty "to provide a safe environment, at all times, for women" so that a "failure in discharging this public duty renders it accountable for the lapse." 59 However, the same insistence also subtly furthers the argument of gender neutrality in rape law.

In this regard:

[g]ender neutrality within rape statutes [means] the concept that the criminal law should recognize that [...] men and women [and transgender persons] can be rape victims as well as perpetrators. [It] reflects modern understandings of the nature, effects, and dynamics of nonconsensual penetrative [and non-penetrative] sex acts[.] $]^{60}$

Premised on this definition, my argument for gender neutrality in Indian rape law is based on the following three distinct arguments.

\section{A. Human Rights and State Obligation}

As iterated above, an act of rape must be viewed solely as a human rights violation. However, such a characterization is theoretically incompatible with the gender specificity prevalent in rape law. If rape is indeed a human rights violation, then a criminal offence of rape that seeks to punish these instances cannot be selective in terms of the protection it affords, on the basis of the genders of the actors involved. Human rights, such as the right to life with dignity and equal protection of the law, are rights that each person is entitled to by reason of being a human being. This includes men, women, and transgender persons to equal extents.

The evidence in support of the above assertion is abundant. The Preamble to the UDHR states that "the inherent dignity and [...] the equal and inalienable rights of

\footnotetext{
57. Alice MILLER and Carole VANCE, "Sexuality, Human Rights, and Health" (2004) 7(2) Health and Human Rights Journal 5 at 9.

58. JVC, Report, supra note 20 at 2 , para 4.

59. Ibid at 3, para 7 .

60. Phil RUMNEY, "In Defence of Gender Neutrality Within Rape" (2007) 6(I) Seattle Journal for Social Justice $48 \mathrm{I}$ at $48 \mathrm{I}$.
} 
all members of the human family is the foundation of freedom, justice and peace in the world". Article 2 of the UDHR provides that "[e]veryone is entitled to all the rights and freedoms set forth in this Declaration, without distinction of any kind, [including] ... sex ... or other status." ${ }^{61}$ Article 7 further states that "[a]ll are equal before the law and are entitled without any discrimination to equal protection of the law. All are entitled to equal protection against any discrimination in violation of this Declaration and against any incitement to such discrimination." ${ }^{62}$ Crucially, Article 8 prescribes that "[e]veryone has the right to an effective remedy by the competent national tribunals for acts violating the fundamental rights granted him by the constitution or by law." $6_{3}$ The use of gender-neutral language in these provisions is deliberate, suggesting that the entitlement of these rights cannot be restricted by factors like sex, and that the protection granted by the legislature in furtherance of these rights must remain uniform.

Admittedly, a literal reading of the above covenants merely reflects a formal, as opposed to a substantive, understanding of equality. While the former equates equal treatment with sameness, the latter is premised on the acknowledgment that at times equal treatment requires the state to treat a class of person differently:

The focus of a substantive equality approach is not simply on equal treatment under the law, but rather on the actual impact of the law.... As Parmanand Singh notes, "it takes into account inequalities of social, economic and educational background ...”. ... The central inquiry ... is whether the rule or practice in question contributes to the subordination of the disadvantaged group. ${ }^{64}$

The Constitution contains provisions for both formal and substantive equality, thereby "suggesting recognition on the part of the founders that uniformly applied formal equality would perpetuate the existing structural inequalities." ${ }^{6}$ In fact, "India's equality jurisprudence has long exhibited inklings of formal equality's limits, undertows, intransigence, and backlash potential, and it displays a vigorous sense that a more substantive notion of equality is needed." 66 On the one hand, Article I4 provides that " $[t]$ he State shall not deny to any person equality before the law or the equal protection of the laws within the territory of India." 67 Similarly, Article I 5 (I) prescribes that " $[\mathrm{t}]$ he State shall not discriminate against any citizen on grounds only of

61. Universal Declaration of Human Rights, GA Res 217(III), UNGAOR, 3rd Sess, Supp No I3, UN Doc A/8Io (I948) 7I, art 2 [emphasis added].

62. Ibid, art 7 [emphasis added].

63. Ibid, art 8 [emphasis added].

64. Ratna KAPUR and Brenda COSSMAN, "On Women, Equality and the Constitution: Through the Looking Glass of Feminism” in Nivedita MENON, ed, Gender and Politics in India (New Delhi: Oxford University Press, I999), I97 at I99-200 (quoting Parmanand SINGH, "Equal Opportunity and Compensatory Discrimination: Constitutional Policy and Judicial Control" (I976) I 8(2) Journal of the Indian Law Institute 300 at 301 ).

65. Deepti SHENOY, “Courting Substantive Equality: Employment Discrimination Law in India” (20I3) 34(3) University of Pennsylvania Journal of International Law 6I I at 6I9.

66. Catharine Alice MACKINNON, "Sex Equality Under the Constitution of India: Problems, Prospects, and 'Personal Laws"” (2006) 4(2) International Journal of Constitutional Law I 8 I at I88.

67. Indian Constitution, supra note 56, art $\mathrm{I}_{4}$. 
religion, race, caste, sex, place of birth or any of them." ${ }^{68}$ However, on the other hand, Article I 5 (3) states that "[n]othing in this article shall prevent the State from making any special provision for women and children." ${ }^{69}$ Therefore, it expressly permits the State to enact any special provisions for women and children "even in violation of the fundamental obligation of non-discrimination among citizens, inter alia of sex". ${ }^{70}$ It is on account of this provision that noted feminists such as Catharine MacKinnon seem to believe that "India's constitutional text holds great potential for ameliorating the subordination of women to men." ${ }^{71}$

One may be tempted to justify the constitutionality of Section 375 of the IPC in terms of Article I5(3). However, despite its ameliorative character, Article I5(3) may also be interpreted as merely enabling the state to provide women and children with higher thresholds of protection, without allowing it to abdicate its constitutional duty to protect its citizens from human rights violations. Further, unlike other jurisdictions,$^{72}$ the offence of rape as defined under Section 375 is the sole offence in Indian criminal law that addresses extreme incidents of sexual assaults that violate a victim's bodily integrity, without any alternate source of redress. Thus, viewed from this perspective, "[t]he case for treating crimes of like heinousness similarly appears to be stronger than that calling for a distinction to be made between penetration of the female body and penetration of the male body, whatever the sex of the actor." 73 Nonetheless, as iterated earlier, my intention here is not to question the constitutionality of Section 375 on the grounds of gender specificity. Instead, I am only attempting to point out its inadequacies in light of the State's constitutional responsibilities.

In this regard, the State's obligation to ensure adherence to the responsibilities arrayed above is not just theoretical. It is widely accepted that states have an obligation to ensure observance of human rights within their territory without discrimination. In fact, General Recommendation I9 on Violence Against Women notes that:

$[\mathrm{D}]$ iscrimination under the [Convention on the Elimination of All Forms of Discrimination Against Women] is not restricted to action by or on behalf of Governments .... For example, under article 2(e) the Convention calls on States parties to take all appropriate measures to eliminate discrimination against women by any person, organization or enterprise. Under general international law and specific human rights covenants, States may also be responsible for private acts if they fail to act with due diligence to prevent violations of rights or to investigate and punish acts of violence, and for providing compensation. ${ }^{74}$

\footnotetext{
68. Ibid, art I $5(\mathrm{I})$.

69. Ibid, art $\mathrm{I}_{5}(3)$.

70. Ministry of Education \& Social Welfare, Government of India, Towards Equality: Report of the Committee on the Status of Women in India (New Delhi: Ministry of Education \& Social Welfare, Government of India, 1974) at 3.

71. MacKinnnon, supra note 66 at I89.

72. See Penal Code (Act 574), (Revd 1997) (Malaysia), s 377CA [Malaysian Penal Code]; Penal Code (Cap 224, 2008 Rev Ed Sing), s 376(2) [Singapore Penal Code].

73. Jocelynne A SCUTT, "Reforming the Law of Rape: The Michigan Example" (1976) 50 Australian Law Journal 6I 5 at 6I7 (quoted in Rumney, supra note 60 at 484).

74. Convention on the Elimination of All Forms of Discrimination Against Women, General Recommendation Number I9, UN CEDAW, I I ${ }^{\text {th }}$ Sess, UN Doc A/47/38 (I992) at para 9.
} 
The doctrine of state obligation that emerged in General Recommendation I9 relied on the idea of state responsibility to protect and fulfil human rights, and built the case that a State could be held accountable for abuses by non-state actors. While doing so, an emerging doctrine on state accountability was strengthened in its codification. ${ }^{75}$ In India, a similar stance was adopted by the National Human Rights Commission as well in an order stating that:

it is the primary and inescapable responsibility of the State to protect the right to life, liberty, equality and dignity of all of those who constitute it. It is also the responsibility of the State to ensure that such rights are not violated either through overt acts, or through abetment or negligence. It is a clear and emerging principle of human rights jurisprudence that the State is responsible not only for the acts of its own agents, but also for the acts of non-State players acting within its jurisdiction. The State is, in addition, responsible for any inaction that may cause or facilitate the violation of human rights. ${ }^{76}$

As such, a State's obligation to ensure the protection of the basic human rights of its citizens within its territory appears to preclude the idea of a gendered protection of the same, thereby casting ample doubts on the appropriateness of gender specificity in Indian rape law, especially when there is no alternative of like seriousness under the Indian criminal law.

\section{B. Judicial Precedents}

The above proposition advocating for gender neutrality in rape law is yet to be considered by an Indian judicial authority, or debated in the Parliament. However, the same is certainly not unprecedented globally.

In 1984 , in People $v$ Liberta, ${ }^{77}$ the Court of Appeals of New York Court was faced with a challenge to the constitutionality of, inter alia, Section 130.35 of New York's Penal Code, which stated that "[a] male is guilty of rape in the first degree when he engages in sexual intercourse with a female ... by forcible compulsion". ${ }^{78}$ The defendant argued that since the provision was not gender neutral, it violated an individual's constitutionally protected right to equality before law. Finding merit in the defendant's argument, the court held that:

Section I 30.35 of the Penal Law violates equal protection because it applies to males who forcibly rape females but exempts females from criminal liability for forcible rape of males ... The fact that the act of a female forcibly raping a male may be a difficult or rare occurrence does not mean that the gender exemption satisfies the constitutional test; a gender-neutral law would indisputably better serve, even if only marginally, the objective of deterring and punishing forcible sexual assaults. ${ }^{79}$

75. Miller, supra note 5I at 24.

76. National Human Rights Commission, Order Dated I April 2002 in Case No II50/6/200I-2002 (New Delhi: National Human Rights Commission, 2002) at para 20(d)(iii).

77. People v Liberta 64 NY 2 d I 52 (I984) [Liberta].

78. Ibid at I 59 (quoting Penal Code (State of New York), s I 30.35 ).

79. Ibid at Headnotes, para 5 . 
Upholding the principle of gender neutrality in rape law, the court added that:

[w] hen a statute is constitutionally defective because of underinclusion, a court may either strike the statute, and thus make it applicable to nobody, or extend the coverage of the statute to those formerly excluded; in making such a decision the court must discern what course the Legislature would have chosen to follow if it had foreseen the court's conclusions as to underinclusiveness. ${ }^{80}$

Thereafter, the court neutralized the gender requirement of the offence altogether.

This decision came as a surprise as it was preceded by the decision of the US Supreme Court (SCOTUS) in I980 in the case of Michael M $v$ Superior Court of Sonoma County. ${ }^{8 \mathrm{I}}$ Therein, the SCOTUS was required to determine whether a California rape statute that punished only males violated the principles of equal protection. By a majority of five to four, the court found the statute to not be unconstitutional for discriminating on the basis of sex as young men and women were not similarly situated with respect to the problems and the risks of sexual intercourse. ${ }^{82}$ Considering the state's strong interest in preventing illegitimate pregnancy, it reasoned that:

Because virtually all of the significant harmful and inescapably identifiable consequences of teenage pregnancy fall on the young female, a legislature acts well within its authority when it elects to punish only the participant who, by nature, suffers few of the consequences of his conduct. It is hardly unreasonable for a legislature acting to protect minor females to exclude them from punishment. Moreover, the risk of pregnancy itself constitutes a substantial deterrence to the young females. No similar natural sanctions deter males. A criminal sanction imposed solely on males thus serves to roughly "equalize" the deterrents on the sexes. ${ }^{83}$

However, in his dissenting opinion, Justice Brennan duly acknowledged that while the objective of preventing teenage pregnancies is credible, the same could also be achieved by a gender-neutral statute without discriminating on the basis of the sex of the offender. He thus found it difficult to reconcile the gender-specific protection afforded by the Californian statute with the SCOTUS's previous opinion in Orr $v$ Orr. ${ }^{84}$

In Orr $v$ Orr, the SCOTUS held a statutory scheme imposing alimony obligations on husbands, but not wives, to be unconstitutional as it violated the equal protection principle. The court's reasoning was that where:

the State's compensatory and ameliorative purposes are as well served by a gender-neutral classification as one that gender classifies, and therefore carries with it the baggage of sexual stereotypes, the State cannot be permitted to classify on the basis of sex. ${ }^{85}$

In the United States, this dictum is regarded as the guiding principle stating the role of gender in legislative classification.

\footnotetext{
80. Ibid at Headnotes, para I.

8I. Michael M $v$ Superior Court of Sonoma County 450 US 464 (I98I).

82. Ibid at $47 \mathrm{I}$.

83. Ibid at 473 .

84. Orrv Orr 440 US 268 (1979) [Orr].

85. Ibid at 283 .
} 
Outside the United States, in I985, the European Court of Human Rights (ECtHR) had an opportunity to comment on state accountability in the context of human rights, albeit in a slightly different situation. In $X \& Y v$ The Netherlands, ${ }^{86}$ the ECtHR found the Netherlands to have breached its responsibilities under Article 8 of the European Convention for the Protection of Human Rights and Fundamental Freedoms, which, inter alia, provides that "[e]veryone has the right to respect for his private and family life, his home and his correspondence." 87 Noting the prosecutor's refusal to initiate criminal proceedings against a man accused of raping a mentally handicapped woman and recognize her father as a substitute complainant, the ECtHR held that Article 8 did:

not merely compel the State to abstain from [arbitrary] interference: in addition to this primarily negative undertaking, there may be positive obligations inherent in an effective respect for private or family life .... These obligations may involve adoption of measures designed to secure respect for private life even in the sphere of the relations of individuals between themselves. ${ }^{88}$

Accordingly, since effective deterrence in this regard could only be achieved via the criminal law, ${ }^{89}$ it concluded that the Netherland's failure to enact an appropriate criminal law addressing the rape of a mentally handicapped woman violated its obligation under Article 8 of the European Convention.

Recently in the 1994 case of Nicholas Toonen $v$ Australia, ${ }^{90}$ the applicant challenged Sections I 22(a)-(c) and I 23 of the Tasmanian Criminal Code, which criminalized various forms of sexual contact between men, against Articles 2, I7, and 26 of the ICCPR. During these proceedings, the State of Tasmania conceded that Section I23 of the Criminal Code clearly draws a distinction on the basis of sex as it prohibits sexual acts only between males. $^{9 \mathrm{I}}$ However, the UN Human Rights Committee found that the challenged provisions violated Articles 2 and I 7 of the ICCPR, and thus did not consider it necessary to discuss whether the statute discriminates on the basis of sex in violation of Article 26. Nonetheless, the key concession made by the State of Tasmania in this regard is sufficient to further my assertion.

The purpose of citing these decisions is not to insist that a gender-specific definition of rape is necessarily unconstitutional, though, as stated in the previous section, the possibility cannot be discarded. Instead, it is to assert that a state's responsibility to ensure the observance of human rights within its territory for persons of all genders must factor in when framing its criminal laws. In the absence of the same, a differential or selective protection of human rights on the basis of gender of either the victim or the perpetrator of rape would be incompatible with the very idea of human rights, as well as gender justice. As highlighted by the Supreme Court of India in its judgment in NALSA, the "[r]ecognition of one's gender identity lies at the heart of the fundamental right to dignity"

\footnotetext{
86. Case of $X$ \& $Y v$ The Netherlands (1985) ECHR 4 [Case of $X$ \&].

87. European Convention on Human Rights, Rome, 4.XI.1950, art 8(I).

88. Case of $X$ \& $Y$, supra note 86 at para 23.

89. Ibid at para 27.

90. Nicholas Toonenv Australia Communication No 488/1992, UN Doc CCPR/C/50/D/488/I992 (I994).

9I. Ibid at para 6.II.
} 
and that "discrimination on the basis of ... gender identity includes any discrimination, exclusion, restriction or preference, which has the effect of nullifying or transposing equality by the law or the equal protection of laws guaranteed under our Constitution". ${ }^{2}$

I will discuss the specifics of the decision in NALSA in the next section. However, at present, it will suffice to state that the argument of gender neutrality in rape law is an argument against the exclusion of genders from the ambit of law aimed at protecting human rights. Absent any other provision to adequately address sexual assaults beyond the traditional notion, and in coherence with the principle of equality before law, the argument for gender neutrality furthers an adaptable understanding of rape that emphasizes the rights of each rape victim, without prioritizing the rights of one gender over others. ${ }^{93}$ In fact, the introduction of gender neutrality allows one to rightly question the archaic binary understanding of gender, an aspect discussed in detail below.

\section{Recognizing Transgender Rights}

Despite undergoing multiple amendments, the definition of rape under the IPC is still affixed to a binary notion of gender. It views rape through a male-on-female paradigm, where men and women are assigned static roles of the perpetrator and the victim respectively. While this victim-perpetrator framework may stem from a push back against the law's tendency to disbelieve a female rape survivor, it is also underinclusive, and therefore damaging. ${ }^{94}$

Irrespective of which gender is assigned what role, an adamant fixation to a male-on-female paradigm compels members of the transgender community to suppress their actual identities, and identify themselves as either males or females. Consequently, certain victims and perpetrators are absent from theories of rape simply because they refuse to sacrifice their gender identity. The laws so framed then present a class of victims of nontraditional sexual assaults with a choice between gender identity and the pursuit of justice. As such, when the traditional notions of sex and gender are transgressed by the transgender community, every progressive society must strive to free itself from such outdated and rigid notions of human nature. ${ }^{95}$ " [T] $\mathrm{T}$ e purpose of the social movement for transgender rights cannot be limited to the right to fail to conform to one's gender identity by choosing to conform to the gender identity of the other sex within the [existing] gender binary." 96 Per contra, its purpose is to legitimize the right to determine one's own gender. In this light, any insistence on gender specificity in rape law stands contrary to the edifice of uninhibited gender justice. It subverts the idea that the reach and promise of sexuality includes individuals without names and identities - the most conventional and privileged along with the

\footnotetext{
92. NALSA, supra note 7 at paras 68 and 77 , respectively.

93. Rumney, supra note 60 at 489.

94. Alletta BRENNER, "Resisting Simple Dichotomies: Critiquing Narratives of Victims, Perpetrators, and Harm in Feminist Theories of Rape" (2013)36 Harvard Journal of Law \& Gender 503 at 567.

95. Melinda CHOW, "Smith v. City of Salem: Transgendered Jurisprudence and an Expanding Meaning of Sex Discrimination Under Title VII" (2005) 28 Harvard Journal of Law \& Gender 207 at 2 I 5.

96. Stevie V TRAN and Elizabeth M GLAZER, “Transgenderless” (2OI2) 35 Harvard Journal of Law \& Gender 399 at 4 I 8 .
} 
most despised ${ }^{97}$ - and reinforces an understanding that only two genders are relevant to any discourse on rape law.

On such basis, one may infer that gender specificity in rape law is, or potentially can be, at loggerheads with the objectives of the queer community that is constantly attempting to expand the binary understanding of gender and incorporate gender nonconformists into the mainstream. Herein, I use the word "queer" in the same manner as understood by Arvind Narrain and David Halperin. For them, queer simply denotes:

"whatever is at odds with the normal, the legitimate, the dominant. [It] demarcates ... a positionality vis-à-vis the normative .... It is from this eccentric positionality occupied by the queer subject that it may become possible to envision a variety of possibilities for reordering the relations among sexual behaviors, erotic identities, constructions of gender, forms of knowledge, regimes of enunciation, logics of representation, modes of self constitution and practices of community." 98

Thus, it is conceivable that any stubborn adherence to gender specificity in rape law not only legitimizes the social hostility towards gender non-conformity in India, but also inadvertently reinforces the heterosexual nature of the legal framework. However, it is essential to note that the mere existence of this tendency may soon become a fatal obstruction for those people who "have been marginalized, discriminated against, ridiculed, and even dehumanized. It is perhaps unsurprising, given this history of stigmatization, that transgendered people have not often found refuge in the law." 99

The assertions above resonate with a recent decision of the Supreme Court of India in respect of transgender rights. In NALSA, the Supreme Court of India was concerned with the grievances of the transgender community, who sought:

a legal declaration of their gender identity [other] than the one assigned to them, male or female, at the time of birth[, their prayer being] that non-recognition of their gender identity violates Articles I4 and 2I of the Constitution of India. ${ }^{\text {IO० }}$

Therein, the apex court duly acknowledged the inability of the Indian legal system to consider the members of the transgender community as belonging to a third gender, and affirmed the right of human beings to choose their own gender. The court's reasoning is of considerable assistance not only due to its substantive content, but also the approach it adopted. Adopting a human rights approach, the apex court reasoned that:

[B]y recognizing [transgender persons] as third gender, they would be able to enjoy their human rights, to which they are largely deprived of for want of this recognition .... [T] he issue of transgender [rights] is not merely a social or medical issue but there is [also] a need to adopt [a human-rights-based] approach towards transgender[] [persons] which may focus on

\footnotetext{
97. Miller and Vance, supra note 57 at 8.

98. Supra note 26.

99. Chow, supra note 95 at 207.

Iоo. NALSA, supra note 7 at para 2.
} 
functioning as an interaction between a person and their environment highlighting the role of society[.] $]^{\text {IOI }}$

Unsurprisingly, the court did not find any reason to hold why a transgender person must be denied their basic human rights, including the right to life and liberty with dignity. ${ }^{102}$ During this process, it not only discarded a binary understanding of gender, but also exposed its sheer incompatibility with the notion of human rights. When extended to the realm of rape law, this reasoning clarifies that a gender-specific definition of rape that is based on, and even furthers, a binary understanding of gender is incompatible with and contrary to the characterization of rape as a human rights violation; especially when there is no other equivalent provision in Indian law to address the excluded class of victims.

It is pertinent to note that none of the directions given by the apex court in NALSA pertain to rape law. Nonetheless, the implications of the decision are far-reaching in various contexts since it reflects an institutional shift in the understanding of gender as a social construct. Thus, it will be futile to view the said decision as being limited to a theoretical recognition of the transgender community as a third gender, and not recognizing their hardship, oppression, and discrimination. After all, as opined by Radhakrishnan, J, the:

[n]on-recognition of the identity of Hijras/transgender persons denies them equal protection of law, thereby leaving them extremely vulnerable to harassment, violence and sexual assault in public spaces, at home and in jail, also by the police. Sexual assault, including molestation, rape, forced anal and oral sex, gang rape and stripping is being committed with impunity and there are reliable statistics and materials to support such activities. ${ }^{\text {IO3 }}$

Given this scenario, to acknowledge the vulnerability of transgender persons to sexual assaults yet continue to exclude them from the definition of rape under the IPC would, in my opinion, constitute an inexplicable and complete abdication of the state's constitutional duty to protect the rights of its citizens, as well as its obligation to ensure observance of human rights within its territory. As such, implementing the true spirit of the NALSA decision necessitates an expansion of the male-on-female paradigm, and a reconsideration of the definition of rape under the IPC.

One may argue that instances of non-consensual same-sex sexual violence can be prosecuted under other provisions such as Section 377 of the IPC, which criminalizes voluntary carnal intercourse against the order of nature as an unnatural offence. ${ }^{\text {I04 }}$ However, even overlooking the fact that the constitutionality of the said provision is itself questionable, the said provision is not an accurate legal basis to criminalize sexual assaults violating a person's bodily integrity, as doing so creates an artificial distinction between sexual assaults that are heterosexual in nature and those that are not. Thus, it not only reinforces a differential attitude towards gender non-conformity, but also

\footnotetext{
IOI. Ibid at para III.

I02. Ibid at para II4.

I03. Ibid at para 55.

I04. Indian Penal Code, I860 (India), s 377.
} 
perpetrates the idea that while heterosexual assaults are acts of rape, the latter only amount to a lesser violation of bodily integrity. Further, there are substantial differences in the punishment awardable for committing an unnatural offence under Section 377 of the IPC and for committing rape. First, while the latter is punishable with imprisonment for a term not less than seven years, ${ }^{105}$ there is no such minimum threshold in case of the former. ${ }^{106}$ Additionally, as per the amended Section 376A, causing the death of a rape victim or committing an act which results in the victim lapsing into a persistent vegetative state is punishable with death. ${ }^{107}$ However, the said provision does not apply to an offence committed under Section 377 . Coupled with its infrequent use to prosecute those engaging in non-consensual "unnatural offences", it is amply clear that Section 377 of the IPC does not provide an adequate alternative to the offence of rape, as punishable under Section 376 of the same Code.

Similar concerns would persist if one desires to address the arrayed inadequacies by enacting a separate gender-neutral offence of like seriousness catering to the nontraditional instances of sexual assault, similar to Section 377CA of the Malaysian Penal Code ${ }^{\mathrm{IO} 8}$ or Section 376(2) of the Singapore Penal Code. ${ }^{\mathrm{109}}$ While such a measure would provide a multitude of victims with the legal protection they were hitherto bereft of, the same is also likely to have inadvertent social consequences. For instance, a conscious decision to not term the equally condemnable acts of sexual violence as "rape" only because they do not conform to the traditional notion diminishes their gravity in the eyes of society. It may be apposite to reiterate the observations of the JVC acknowledging that the term "rape" is understood as an expression of society's strong moral condemnation. ${ }^{\text {II }}$ In fact, the Committee, while referring to the offence of "sexual assault" defined under Section 265 of the Canadian Criminal Code, opined that:

[t]he disadvantage of this approach is that the epithet "rape" continues to bring with it a high degree of moral and social opprobrium, which is not conveyed by the words "sexual assault." By removing the epithet "rape", there is a risk of diluting the extent of moral condemnation. ${ }^{\text {II I }}$

In harmony with the above, I believe this moral condemnation ought to be extended beyond the male-on-female paradigm as well. Acknowledging that rapes have historically been a tool for gender subordination does not constitute a sufficient justification to distinguish sexual assaults on the basis of a gendered characterization of the victim-perpetrator framework. It ignores the fact that though rape is an act of power, this power differentia between a perpetrator and a victim need not be based on their respective genders, but can be a consequence of other power structures based on, for example, caste, race, or economic differences. Most importantly, the failure to

\footnotetext{
I05. Ibid, s $376(\mathrm{I})$.

I06. Ibid, s 377 .

I07. Ibid, s 376A.

I08. Malaysian Penal Code, supra note 72, s 377CA.

I09. Singapore Penal Code, supra note 72, s 376(2).

I Io. JVC, Report, supra note 20 at I I I, para 67.

I II. Ibid at I07, para iv.
} 
recognize a class of sexual assaults as rape is likely to trivialize the experiences of those who do not conform to the male-on-female paradigm. Therefore, from a holistic perspective, enactment of separate gender-neutral offences, while retaining the gender specificity in the offence of rape, is certainly convenient, but not ideal. Yet, considering the broader objectives of gender justice and the need to provide legal redress to a large number of rape victims outside the traditional notion, it will nonetheless be construed as a step in the right direction, even if an imperfect one. What remains crucial is to recognize that the victims and perpetrators of sexual violence can be men, women as well as transgender persons.

\section{THE ARGUMENT AGAINST GENDER NEUTRALITY}

In the previous sections, I have argued that the State does not enjoy much discretion in protecting human rights within its territory. However, this does not mean that a State does not possess any margin of appreciation in framing its laws in accordance with its social conditions on the ground. This margin of appreciation is the birthplace of the three common arguments against gender neutrality in Indian rape law that merit attention.

\section{A. Statistical Evidence and Gender Non-Conformity}

The first argument against gender neutrality in rape law is that, unlike with women, there are no official statistics to evidence that non-females are raped in India or that women can rape another person. This argument draws support from an underlying belief that "it is still men who are raping and women who are being raped" and that "gender neutral rape laws do not reflect the reality of rape." II2 It also furthers the historically supported understanding that "rape is 'a conscious process of intimidation by which all men keep all women in a state of fear'" . ${ }^{\text {II3 }}$ Indeed, after the constitution of the JVC, a plethora of feminist groups had suggested that a gender-neutral definition of rape implies "that women can commit sexual assault against men for which there is no empirical evidence at all". ${ }^{\mathrm{II} 4} \mathrm{~A}$ few others were more conscious, stating that "nearly $97 \%$ of the survivors of rape or sexual assault are women", ${ }^{15}$ or that there have been a "negligible number of cases where women have been

I I2. Phil RUMNEY and Martin MORGAN-TAYLOR, "Recognizing the Male Victim: Gender Neutrality and the Law of Rape: Part One” (I 997) 26 Anglo-American Law Review I 98 at 207-208 (quoting Ngaire NAFFINE, "Possession: Erotic Love in the Law of Rape" (I994) 57(I) Modern Law Review Io at 24) and 2 IO.

I 13. Flavia AGNES, "Law, Ideology and Female Sexuality: Gender Neutrality in Rape Law" (2002) 37(9) Economic and Political Weekly 844 at 844 (quoting Susan BROWNMILLER, Against Our Will: Men, Women and Rape (Harmondsworth: Penguin, 1976)).

II4. PLD, "Submissions to Justice Verma Committee by All India Democratic Women's Association (AIDWA) and Women's Groups" (4 January 20I3) at 4, online: PLD <http://feministlawarchives. pldindia.org/wp-content/uploads/submissions-by-all-india-democratic-women.pdf> [PLD, "AIDWA”]. See also PLD, "Submissions to the Committee headed by Justice J.S. Verma" (5 January 20I3) at I, online: PLD <http://feministlawarchives.pldindia.org/wp-content/uploads/submissions-by-pld-to-justiceverma-committee.pdf $>$.

I I 5. PLD, "Submissions to the Justice Verma Commission by Jagori" (4 January 20I3) at I, online: PLD <http://feministlawarchives.pldindia.org/wp-content/uploads/submissions-by-jagori.pdf $>$. 
the perpetrators." ${ }^{16}$ Similar suggestions were also made by the People's Union for Civil Liberties, ${ }^{\mathrm{I} 7}$ the prominent human-rights Advocate Ms Vrinda Grover, ${ }^{\mathrm{II} 8}$ and the Women's Research and Action Group, Mumbai. ${ }^{\text {II9 }}$ In effect, the opinion endorsed by most feminist groups is that:

throughout the two decades of struggle, not a single case of a reversal of gender roles, in the realm of sexual offence, had ever surfaced in the Indian context nor at any time formed part of the discourse. In this entire history, no one has ever advanced the plea of sexual violation by women. ${ }^{\text {I20 }}$

At the outset, it is helpful to note that feminists have long recognized sexual assaults beyond the male-on-female paradigm without obstructing themselves from highlighting issues of gender inequality or female victimization. ${ }^{\text {II }}$ To quote Susan Brownmiller, a renowned feminist author:

[W] hile the penis may remain the rapist's favorite weapon, his prime instrument of vengeance, his triumphant display of power, it is not in fact his only tool. Sticks, bottles and even fingers are often substituted for the "natural" thing. And as men may invade women through other orifices, so, too, do they invade other men. Who is to say that the sexual humiliation suffered through forced oral sex or rectal penetration is a lesser violation of the personal, private inner space, a lesser injury to mind, spirit and sense of self?

All acts of sex forced on unwilling victims deserve to be treated in concept as equally grave offenses in the eyes of the law, for the avenue of penetration is less significant than the intent to degrade. Similarly, the gravity of the offence ought not be bound by the victim's gender. That the law must move in this direction seems clear. ${ }^{\mathrm{I} 22}$

Likewise, in its recommendations to the JVC, Alternative Law Forum had recommended that the conceptualization of a victim be broadened from a "woman" to a "person" so as to protect those who are assaulted on grounds of their gender identity. In particular, it had acknowledged that:

sexual violence is always gendered and [...] is perpetrated on account of one's gender. Thus it is not only women, but all those who are perceived to be transgressing the boundaries of gender who are subject to sexual assault. This [category] includes female to male transsexuals, hijras, kothis, effeminate gay men and all those who violate the social codes

\footnotetext{
I 16. PLD, “Submissions to Justice Verma Committee by Lawyers Collective” (January 20I3) at 6, online: PLD $<$ http://feministlawarchives.pldindia.org/wp-content/uploads/submissions-by-lawyers-collective.pdf [PLD, "Lawyers Collective"].

I 7. PLD, "Submissions to Justice Verma Committee by PUCL" (January 20I3) at 5, online: PLD <http:// pldindia.org/wp-content/uploads/2013/o3/Submissions-by-PUCL.pdf $>$.

I 8. PLD, "Submissions to Justice Verma Committee by Vrinda Grover” (5 January 20I3) at 6, online: PLD $<$ http://feministlawarchives.pldindia.org/wp-content/uploads/submissions-by-vrinda-grover.pdf $>$.

II9. PLD, "Submissions to Justice Verma Committee by Women's Research \& Action Group (WRAG), Mumbai” (January 2013) at 3, online: PLD <http://feministlawarchives.pldindia.org/wp-content/ uploads/submissions-by-wrag.pdf $>$.

I20. Agnes, supra note II 3 at 846 .

I2I. Rumney, supra note 60 at 49 I.

I22. Susan BROWNMILLER, Against Our Will: Men, Women and Rape (New York: Ballantine, I975) at 378 .
} 
of gender. Our proposal is rooted in the concrete history of discrimination and seeks to extend protection to vulnerable groups. ${ }^{\mathrm{I} 23}$

Thus, the objective of gender equality need not always be inconsistent with recognizing non-female victims of rape.

This notwithstanding, my response to the first argument against gender neutrality in rape law is twofold.

First, a gender-specific definition of rape based on the male-on-female paradigm not only associates the victim and the perpetrator with a specific gender, but also the various stereotypes associated with it. There are countless theories of gender which further the idea that "gender and sex are fixed notions that are inherently linked: men are, or should be, masculine, and women are, or should be, feminine." ${ }^{24}$ This creates a perception wherein a male perpetrator is not only a man, but someone who demonstrates masculine aggression, and a female victim is associated with a sense of passive feminine subordination. Therefore, in addition to belonging to specific genders, rape victims and perpetrators are expected to behave in accordance with their gendered roles for any sexual assault to constitute rape. This is identical to Zsuzsanna Adler's description of an ideal rape, where each participant to an act of rape is required to behave in a particular manner, conforming to the expectations from each gender. For instance, while rape victims must be sexually inexperienced and possess good character, rape perpetrators must use physical force. ${ }^{\mathrm{I} 25}$

In India, several attempts have been made to address the aforementioned concerns, and limit the frequent references to gender-based stereotypes. As noted in the JVC Report, "evidence of the victim of rape is on the same footing as the evidence of an injured complainant or witness. Her testimony alone is sufficient for conviction." ${ }^{26}$ Additionally, in certain cases of aggravated rape under Section 376(2) of the IPC, the burden of proving "consent" is placed upon the accused. ${ }^{\text {I27 However, }}$ notwithstanding these efforts, the dangers of stereotyping roles continue to plague the Indian criminal justice system even today.

The constant association of the victim/perpetrator framework with gendered roles encourages a legal system to label rape perpetrators as "beasts" ${ }^{\text {I28 }}$ or "sex-starved wolves". ${ }^{\text {I29 }}$ This particular risk was noted even by the SCOTUS in Orr $v$ Orr, when it opined that:

[1] egislative classifications which distribute benefits and burdens on the basis of gender carry the inherent risk of reinforcing stereotypes about the "proper place" of women and

\footnotetext{
I23. PLD, “Submissions to Justice Verma Committee by Alternative Law Forum, Bangalore” (January 20I3) at 2, online: PLD <http://feministlawarchives.pldindia.org/wp-content/uploads/submissions-byalternative-law-forum.pdf $>$.

I24. David S COHEN, "Sex Segregation, Masculinities, and Gender-Variant Individuals" in Frank Rudy COOPER, Ann C McGINLEY, and Michael KIMMEL, eds, Masculinities and the Law: A Multidimensional Approach (New York: NYU Press, 20I 2), I67 at I7I [Cohen, "Sex Segregation"].

I 25. Zsuzsanna ADLER, Rape on Trial (London: Macmillan Press, I987) at IO2-I 20.

I26. JVC, Report, supra note 20 at 78 , para I7.

I27. Indian Evidence Act, 1872 (India), s I I4A.

I 28. State $v$ Ram Singh \& Ors SC No I I $4 / 20 \mathrm{I}_{3}$ (describing the convicts' conduct as "beastly").

I29. Amit BARUAH, "Dealing with 'Wolves' and 'Beasts'" The Hindu (26 April 20I4), online: The Hindu $<\mathrm{http}: / /$ www.thehindu.com/todays-paper/tp-opinion/dealing-with-wolves-and-beasts/article 5949878.ece>.
} 
their need for special protection. [...] Thus, even statutes purportedly designed to compensate for and ameliorate the effects of past discrimination must be carefully tailored. ${ }^{130}$

At first, the said tendency appears harmless. However, over time, it creates a situation where if either participant to an act of rape does not conform to his or her role, then one finds it difficult to recognize the incident as an act of rape or attach blameworthiness to the perpetrator. ${ }^{\mathrm{I}{ }^{\mathrm{I}}}$ The judicial decisions reflecting this tendency are plenty. ${ }^{\mathrm{I}{ }^{2}}$ In my opinion, if the wisdom of the judges falls prey to such stereotypes rather frequently, then not many can be considered immune. In this light, the first argument against gender neutrality may well be a product of the sheer inability or reluctance to acknowledge the occurrence of rapes beyond the traditional notion, where actors do not demonstrate the expected behaviour. Indeed, Alletta Brenner fears that "[s]uch a finding seems surprising only because the victim/perpetrator framework simultaneously constructs male sexual desire as ever-present and aggressive, female sexual desire as absent or passive, and the male/female sexual relations as defined by male dominance and female subordination." ${ }^{133}$ It would not be unreasonable to extend her opinion to the Indian scenario where various other power structures which are not based on gender continue to ply with great force. As acknowledged by Laxmi Murthy:

[w]omen too are capable of perpetrating sexual assault on men ... and also on other women. [Such instances are] more possible in situations of custody ... or situations of caste/communal violence etc[.], where women may collude, or actually initiate sexual assault on men of lower castes/ minority communities. ${ }^{\text {I34 }}$

Accordingly, gender neutrality may allow us to abrogate sex stereotypes, and move beyond an understanding of men as the natural aggressors and women as the perennial victims. $^{\text {135 }}$

Second, it cannot be denied that there are likely to be no statistics in India to evidence sexual assaults beyond the traditional notion of rape. This, however, does not lead to a conclusion that such instances do not occur. The absence of any official statistics is explainable on three counts.

One, in the context of male victims, there is an anti-masculinity stigma attached to any form of sexual assault, discouraging them from reporting an incident of victimization. This is commonly referred to as hegemonic masculinity, which is the "most honored way of being a man, [...] requir[ing] all other men to position themselves in relation to it, and [...] ideologically legitimat[ing] the global subordination of women to men." ${ }^{36}$

I30. Orr, supra note 84 at 283 .

I3I. Brenner, supra note 94 at 520.

I32. Commonwealth v Berkowitz 64I A2d II6I (I993).

I33. Brenner, supra note 94 at 528 .

134. PLD, "Comments by Laxmi Murthy", supra note 2 at 3.

I35. Deborah DENNO, "Why the Model Penal Code's Sexual Offense Provisions Should Be Pulled and Replaced" (2004) I Ohio State Journal of Criminal Law 207 at 2 I I.

I36. R W CONNELL and James W MESSERSCHMIDT, "Hegemonic Masculinity: Rethinking the Concept" (2005) I9(6) Gender \& Society 829 at 832. 
Supplemented by continuous sexual segregation in society, "three important characteristics of [...] hegemonic masculinity [are] that men are not feminine, are heterosexual, and are physically aggressive." ${ }^{\text {I37 }}$ In a patriarchal society, this creates a popular, but unfounded perception that men who are raped are rendered female by it. ${ }^{138}$ Such perceptions go on to demonstrate how men experience rape and its reporting as a threat to their masculinity and concept of self. ${ }^{\mathrm{I} 9}$ In a society that celebrates masculinity, men are stereotypical aggressors. However, men, like women, are also bound by stereotypes, perpetuated in society and legitimized by law, which deny them opportunities for self-definition and coerce them into stifling identities. ${ }^{\mathrm{I}}{ }^{\circ}$ Thus, social constructs of patriarchy also discourage men from registering their complaints if they are sexually assaulted, especially where the perpetrator is a woman. ${ }^{\mathrm{I} 4 \mathrm{I}}$

Two, sociological studies have indicated that there is a likelihood of blaming the victim for their experience of rape, notwithstanding whether the victim is male, female, or transgender. ${ }^{\mathrm{I}}{ }^{2}$ In the context of women, this tendency of victim-bashing drew the ire of the JVC Report when it stated that:

even after the recent horrific incident of gang rape, many political leaders, ... spiritual gurus ... and other eminent persons have been making statements reinforcing the gender bias. Some have even blamed the victim for having facilitated the rape by her own behaviour. $^{\mathrm{I}}{ }^{3}$

While the JVC's observations were with regard to sexual violence against women, the tendency of victim bashing creates a socially hostile environment for victims of all genders. For example, many gay men may avoid seeking help because they do not know how the police will treat them, ${ }^{\mathrm{I} 44}$ or because they are afraid that " "people will forget the rape and blame [them] for hooking up with [strangers], especially [other men]." I45 Accordingly, this tendency of repositioning the blame on the rape victim, irrespective of gender, contributes to the absence of any statistical evidence on the issue.

Three, there is an additional consideration justifying the absence of official statistics on the issue, especially in the context of transgender persons. In India, there is no law that recognizes rape beyond the traditional notion, which makes it more difficult for non-female victims to file a complaint with an insensitive police establishment.

I37. David S COHEN, “Keeping Men 'Men' and Women Down: Sex Segregation, Anti-Essentialism, and Masculinity" (20I0) 33 Harvard Journal of Law \& Gender 509 at 525.

I38. Patricia NOVOTNY, "Rape Victims in the Gender Neutral Zone: The Assimilation of Resistance?" (2003) I Seattle Journal for Social Justice 743 at 744 .

I39. Nathan W PINO and Robert F MEIER, "Gender Differences in Rape Reporting" (I999) 40 Sex Roles 979.

I40. John M KANG, “The Burdens of Manliness" (2010) 33 Harvard Journal of Law \& Gender 477 at 477.

I4I. Rumney and Morgan-Taylor, supra note II 2 at 207.

I42. Rumney, supra note 60 at 498-499.

I43. JVC, Report, supra note 20 at II, para 23.

I44. Priya M MENON, "Lacking Support, Male Rape Victims Stay Silent” The Times of India (I 6 February 2013), online: The Times of India <http://timesofindia.indiatimes.com/city/chennai/Lacking-supportmale-rape-victims-stay-silent/articleshow/I 8524668 .cms> [Menon, "Stay Silent"].

I 45. KRISHNA, "The Unheard Victims of Violence" The Hindu (3 September 20I3), online: The Hindu <http:// www.thehindu.com/features/metroplus/society/the-unheard-victims-of-violence/article 50883 I I.ece $>$. 
For communities only recently afforded a legally-recognizable gender identity, such concerns immediately multiply. As such, "[t]he historic failure of the legal process in most jurisdictions to recognize rape outside the male-on-female paradigm may have also contributed to the failure of society to acknowledge male [or transgender] sexual victimization." ${ }^{\mathrm{I} 46}$ In any event, the absence of official statistics evidencing nontraditional cases of rape ought to be viewed in the appropriate social context, especially after the apex court acknowledged how members of the transgender community are often subjected to rape and other forms of sexual assault. ${ }^{\mathrm{I}}{ }^{7}$ Therefore, the statistical imperfections do not afford a legitimate basis to deny the need to revisit the issue of gender neutrality in rape law.

Nonetheless, I acknowledge that instances of sexual assault beyond the traditional notion of rape will be few in comparison to those that conform to the male-onfemale paradigm. However, the potential size of the class of victims likely to benefit from the suggested reforms must remain irrelevant to any discourse in law. If not, then such an argument would be disastrously similar to the appalling reasoning adopted by the Supreme Court of India in Suresh Kumar Koushal $v$ NAZ Foundation ${ }^{\mathrm{I} 48}$ while upholding the constitutional validity of Section 377 of the IPC, which criminalizes consensual sex between adults of the same sex. The apex court reasoned that only:

a miniscule fraction of the country's population constitute lesbians, gays, bisexuals or transgenders and in [the] last more than I 50 years less than 200 persons have been prosecuted ... for committing [an] offence under Section 377 [of the] IPC and this cannot be made sound basis for declaring that section ultra vires the provisions of Articles I 4, I 5 and $2 \mathrm{I}$ of the Constitution. ${ }^{\mathrm{I} 9}$

This line of reasoning was described as "counterintuitive to the notion of discrete and insular minorities who are unable to fend for themselves or use the political process and in need of judicial intervention to protect their rights and freedoms." ${ }^{50}$ Many considered it to be an abdication of the responsibility to protect all minorities from the vicissitudes of the majority's opinion, and some mockingly labelled it as "the rise of a constitutional numerical equality test". ${ }^{\text {I5 }}$ Similarly, the fact that instances of nontraditional rapes may only constitute a miniscule fraction of total rapes ought not to hold any relevance.

As pointed out by the Court of Appeals of New York in People $v$ Liberta:

while forcible sexual assaults by females upon males are undoubtedly less common than those by males upon females this numerical disparity cannot by itself make

\footnotetext{
I46. Rumney, supra note 60 at 485 .

I47. See NALSA, supra note 7 at para 55.

I48. Suresh Kumar Koushal \& Anrv NAZ Foundation \& Ors (20I4) I SCC I.

I49. Ibid at para 43 .

I 50. Siddharth NARRAIN, "We Dissent” Kafila (I 2 December 20I3), online: Kafila <http://kafila.org/20I3/ I 2/I 2/we-dissent-siddharth-narrain/>.

I 5I. Danish SHEIKH, “Crimes of Unreason” Kafila (I 2 December 20I3), online: Kafila <http://kafila.org/ 2013/I2/I 2/crimes-of-unreason-danish-sheikh/>.
} 
the gender discrimination constitutional. Women may well be responsible for a far lower number of all serious crimes than are men, but such a disparity would not make it permissible for the State to punish only men who commit, for example, robbery $[\ldots] .^{152}$

Consequently, "while females are the main victims of sexual violence and males the main perpetrators, one still has to consider how sexual assaults beyond the male-onfemale paradigm are to be labeled by the criminal law." ${ }^{53}$

\section{B. The Threat of Countercomplaints}

The second common argument against gender neutrality in Indian rape law pertains to the ill-effects of recognizing women as potential perpetrators in an incident of rape. Many consider patriarchal societies like those in India to be ill-prepared to accept a completely gender-neutral definition of rape since doing so would introduce a serious threat of countercomplaints being filed against every bona fide woman complaining of being raped. In other words, if the offence of rape is made completely gender-neutral, it "will allow men to file false cases of penetrative sexual assault against women". ${ }^{154}$ As a result, for every complaint of rape by a woman, there will be a countercomplaint filed by the accused man, which will deter female rape victims from coming forward. ${ }^{\text {I }} 55$

In such a scenario, it is strongly argued that "[a] gender-neutral rape law would open up avenues for inflicting even greater trauma and humiliation to an already marginalised section and hence defeat the very purpose of reform", ${ }^{156}$ and would erode "the deterrence value of criminalizing rape as it will inevitably be used against women in rape trials, where men will state that women were [the] aggressors". ${ }^{157}$ As such, many consider it prudent to "be suspicious of the way that a gender neutral lens not only obscures facets of women's oppression[, but] also provides the tools ... for dismantling some of the gains that have been made for women." ${ }^{158}$ In India, these concerns stand further elevated due to the apathetic and insensitive nature of the legal process -starting from the time of registering a complaint with the police to the ordeal that a rape trial is. Even the JVC noted that " $[t]$ here is, naturally, a certain degree of institutional bias against women. Their complaints are not taken seriously by the police. On account of the patriarchal structure the male police officers do not take complaints of rape seriously." " 59

\footnotetext{
I 52. Liberta, supra note 77 at I69-I70.

I 53. Rumney, supra note 60 at 497.

I 54. See PLD, “AIDWA”, supra note I 4 at 4.

I 5. Farah NAQVI, "For the Women of India, Parliament Must Speak" The Hindu (7 March 20I3), online: The Hindu <http://www.thehindu.com/opinion/op-ed/for-the-women-of-india-parliament-must-speak/ article 4482470. ece $>$.

I 56. Agnes, supra note I I 3 at 847 .

I 57. PLD, "Lawyers Collective", supra note i i 6 at 6.

I 58. Nicola GAVEY, "Violence Against Women: Beyond Gender Neutrality" (Co-Presented with Alison TOWNS at The Women's Convention, 3-6 June, 2005, Wellington, New Zealand) at 6, online: New Zealand Family Violence Clearinghouse <https://nzfvc.org.nz/sites/nzfvc.../Violenceagainstwomenneutralityo5.doc>.

I 59. JVC, Report, supra note 20 at 48 , para 57.
} 
However, the very existence or extent of this threat is contingent upon the filing of a countercomplaint by a man against a woman, which is by no means a certainty. The continuous and overbearing emphasis on masculinity deters men from voicing their sexual victimization by another person, especially a woman. As noted by the JVC:

a simple examination of male experience shows that boys are expected to achieve masculinity at all odds to prove their manhood through a process of social or psychological evolution using various messages .... "Such exercise of power and violence against women and other men not only structure man-woman relationships, but also among men themselves in society...". ${ }^{\text {160 }}$

Thus, "[w] hereas women have had to suffer the discrimination that derives from being perceived as physically and emotionally weak, men have had to endure the discrimination that derives from being perceived as bearers of physical courage." ${ }^{\text {6I I }}$

In such light, to file a countercomplaint of rape, men, much like women, must be desirous of braving an agonizing trial process that will question their masculinity at every stage. Assuming the existence of such courage as a foregone conclusion, however, is unreasonable. Some wonder if they will even be believed to begin with, ${ }^{162}$ while many others doubt whether others will take the crime seriously and fear becoming the "'butt of myriad jokes." ${ }^{163}$ This illustrates that the social barriers that tend to make the criminal justice system inaccessible for women also hinder the ability of men to file a rape complaint against another person. After all, "most gender theorists acknowledge the simple fact that the dominant societal notion of being masculine means 'doing things that cannot and should not be done by women'." ${ }^{164}$ Accordingly, this consideration must be factored in to mitigate the perceived threat of a countercomplaint.

In any event, an imperfect social structure plagued with patriarchy is no reason to discard the idea of gender neutrality in rape law as the entitlement of human rights is not contingent upon the cultural, or legal, idiosyncrasies of a society. This statement is premised on the universality of human rights, which states that human rights are universal in nature and apply to human beings despite cultural or social differences. ${ }^{165}$ As noted by Fernando Tesón, albeit in response to the theory of cultural relativism:

to say that cultural identities should be respected does not mean that international human rights law lacks a substantive core .... Unless one wishes to give up the very notion of an international law of human rights altogether, these rights should have essentially the same meaning regardless of local traditions. ${ }^{166}$

\footnotetext{
I60. Ibid at 386, para Io (attributing the quotation to Andrew E Taslitz).

I6I. Kang, supra note I40 at 507.

I62. Menon, "Stay Silent", supra note I44.

I63. Krishna, supra note I45.

I64. Cohen, "Sex Segregation", supra note I 24 at I 75 (quoting Ellen JORDAN, "Fighting Boys and Fantasy Play: The Construction of Masculinity in the Early Years of School" (I995) 7(I) Gender and Education 69 at 75 ).

165. Fernando R TESÓN, "International Human Rights and Cultural Relativism” ( 1985 ) 25 Virginia Journal of International Law 869 at 873 .

I66. Ibid at 874 .
} 
Tesón's opinion expounds the idea that while sovereign nations are capable of asserting various human rights demands in different modalities, there is an almost universal insistence on certain basic values among all cultures. ${ }^{167} \mathrm{I}$ believe this principle of the universality of human rights firmly contradicts the legitimate, but slightly misplaced second argument against gender neutrality in Indian rape law. It is true that the risk of a false countercomplaint cannot be completely eliminated. However, it does not permit any state to abdicate its constitutional responsibilities and turn a blind eye to human rights violations occurring within its territory. Introducing gender neutrality in rape law neither addresses nor aggravates this concern, which has its roots in the very structure of society. Accordingly, a possible solution to these concerns is not in the selective protection of human rights through underinclusive criminal laws, but rather in institutional and educational measures.

\section{Undermining the Gendered History of Rape}

The third argument against gender neutrality is relevant from the perspective of both the victim and the perpetrator. Much more than a deliberate attempt to intimidate and harass women, rape "has been one of the means through which the social hierarchy of power relationships is maintained and nurtured in a gendered society." "68 In light of such gendered history, feminists conceptualize rape exclusively in the context of the deeply entrenched power inequalities between men and women. ${ }^{169}$ The same is consistent with the UN Handbook for Legislation on Violence Against Women, which clearly recommends that legislation be gender-sensitive, and not gender-blind. ${ }^{\mathrm{I}}{ }^{70}$ As per the Commentary to this recommendation, a gender-sensitive approach ought to acknowledge that "women's and men's experiences of violence differ and that violence against women is a manifestation of historically unequal power relations between men and women and discrimination against women." ${ }^{\mathrm{IT}}$ This leads to a fear that introducing gender neutrality in rape law would erode the history of the offence, undermine its use as a tool for gender subordination, and compel an analysis that ignores its role in perpetrating gender inequality in society.

To quell this fear, one must revisit the meaning and purpose of gender neutrality in rape law. By gender neutrality, I only refer to a more expansive definition of the offence of rape from the perspective of the victim and the perpetrator that includes, but is not limited to, a male-on-female paradigm. The conceptual alternation only extends to include non-female victims and non-male perpetrators within the notion of rape, and nothing more. ${ }^{\mathrm{I} 2}$ By making this suggestion, I do not suggest

\footnotetext{
I67. See Eric LANE, “Demanding Human Rights: A Change in the World Legal Order?” (I978) 6 Hofstra Law Review 269.

I68. Agnes, supra note I I 3 at 844 .

I69. See Menon, "Gender Just Laws", supra note 24.

I70. UN DESA, supra note 52 at 15.

I7I. Ibid.

I72. Rumney, supra note 60 at 486 .
} 
an ungendered analysis of rape. The idea of gender neutrality requires equality, and not the neutralization of gender as a relevant factor in the analysis of the offence. $^{\mathrm{I} 73}$

In fact, I agree that rape is an act of power. However, "within a single interaction, power may operate in multiple, intersecting, and sometimes competing ways." ${ }^{\mathrm{I} 74}$ To construct the interplay between a rape victim and a perpetrator, and to identify the power differentia between the two solely on the basis of their respective gender is rather oversimplistic. After all, "sexuality varies in complex ways across time and place in a manner we are just beginning to apprehend, despite its ... allegedly unchanging and static nature." ${ }^{175}$ As such, the introduction of gender neutrality in rape law is necessary because it grants flexibility to an already heterosexual framework in order to appreciate that rape can be motivated by power differentia which are not based on gender.

From this perspective, gender neutrality does not undermine the history of rape, but allows one to perceive other elements of power that may be relevant to our understanding of rape. In the words of Arvind Narrain, “[v]ictimhood depends upon a host of circumstances including the motivation of the perpetrator. If it is indeed to humiliate the victim on account of his or her membership in a particular community, the gender of the victim is irrelevant." ${ }^{176}$ For example, in armed conflicts, rape becomes a mark of victory. In ethnic wars, it is an act of assertion of power on the members of an ethnic tribe notwithstanding their gender. Such assaults are then best described as "gratuitous acts and extravagant defilements" committed on bodies which are both male and female. ${ }^{\mathrm{I} 77}$ Accordingly, in addition to its historically supported description as a tool for gender subordination, rape can also simultaneously constitute a form of aggression used for the intimidation, degradation, humiliation, discrimination, control, or destruction of a person. ${ }^{178}$

In the context of the Model Penal Code, Deborah Denno opines that " $[\mathrm{b}] \mathrm{y}$ understanding how rape laws were influenced in the past, we have a better idea of how they can be reshaped in the future." ${ }^{179}$ However, this must not become an obstacle to the evolution of rape law jurisprudence with the changing facets of time and society. ${ }^{\mathrm{I}}{ }^{\circ}$ Many contemporary academicians now consider the gender specificity of the offence of rape codified in the Model Penal Code to be a problem, and a gender-neutral approach to be more desirable. Even the Commentary to the Penal Code states rather forthrightly that " "[i]f the Model Code were being redrafted today, it might well be that preserving these [gender] differences would not be thought to outweigh the advantages of describing the entire offense of rape in

\footnotetext{
I73. Novotny, supra note 138 at 748 .

I74. Brenner, supra note 94 at 523 .

175. Miller and Vance, supra note 57 at 6.

I76. Arvind NARRAIN, "Violation of Bodily Integrity: The Delhi Rape Case Among Others" (20I3) 48(I) Economic and Political Weekly I7 at I9.

177. Ibid at I 8 (attributing the term to Susan Brownmiller).

I78. Ibid.

I79. Denno, supra note $\mathrm{I} 35$ at 208.

I80. Ibid.
} 
gender-neutral terms." " ${ }^{\text {I8 }}$ I believe that this adequately explains that the definition of rape can be redefined in gender-neutral terms and still remain true to its historically accepted meaning.

In any event, considering that gender is itself a dynamic social construct, evolving with time, it would be futile to adhere rigidly to an archaic notion of rape to the exclusion of gender groups that lack adequate historical recognition, such as transgender persons. Accordingly, to quote Phil Rumney:

gender-neutral reforms are not designed to make gender irrelevant in our understanding of sexual violence; in fact, gender is central to any understanding of how and why sexual violence occurs. What is clear, however, is that while females are the main victims of sexual violence and males the main perpetrators, one still has to consider how sexual assaults beyond the male-on-female paradigm are to be labeled by the criminal law. ${ }^{\mathrm{I} 82}$

\section{CONCLUSION}

Much of the opposition towards gender neutrality in rape law can be traced to an incorrect understanding of what it actually means. It presupposes that " $[\mathrm{u}]$ nderlying this recommendation is a presumption that, through a stroke of a pen, the offence of rape will be desexualised and the stigma attached to the offence will vanish." ${ }^{83}$ However, the said presumption is flawed. The purpose of gender neutrality is not to desexualize rape, but rather to develop an understanding of the offence that travels beyond a male-on-female paradigm. Gender neutrality "will not [...] change attitudes and behaviour ... [f]or the paradigm shift [...] requires not only linguistic but institutional and social reform." ${ }^{84}$ Thus, it is imperative to address the institutional concerns plaguing the Indian criminal justice system, like harrowing procedures, lax and corrupt investigative machinery, and degrading cross-examinations of the victims, to ensure that rape trials do not remain an ordeal for the victim. The same may then make gender neutrality a far more attractive proposition.

That said, I am now in a position to answer the questions about whether the offence of rape ought to be made gender-neutral from the perspectives of (i) the victim and (ii) the perpetrator, respectively.

From the victim's perspective, the characterization of rape as a human rights violation imposes an obligation upon the state to protect its citizens from violations of their bodily integrity and sexual autonomy without any discrimination, inter alia, on the basis of sex. This contention is strongly supported by the apex court's decision in NALSA, which acknowledges the suffering of the transgender community, and their vulnerability to sexual assaults. As such, the law must evolve along with visible changes in social constructs. Any argument to the contrary, premised either on a lack of

I8I. Denno, supra note $\mathrm{I} 35$ at 210-2I I (quoting American Law Institute, The Model Penal Code and Commentaries: (Official Draft and Revised Comments) (Philadelphia: American Law Institute, I980) at 337 (art 213, s 213.I, cmt 6)).

I82. Rumney, supra note 60 at 497.

I83. Agnes, supra note II 3 at 844 .

I 84. Annabelle MOONEY, "When a Woman Needs to Be Seen, Heard and Written as a Woman: Rape, Law and an Argument Against Gender Neutral Language" (2006) International Journal for the Semiotics of Law 39 at $42-43$. 
evidence or the infrequency of nontraditional rapes, appears to be misplaced. Thus, there is a pressing need to make the offence of rape gender-neutral from the victim's perspective, a proposition on which most organizations working in the interests of women and sexual minorities tend to agree. ${ }^{185}$

From the perpetrator's perspective, to defer the theoretically prudent and socially imperative need for gender neutrality in rape law indefinitely on the basis of a hope that society will one day rid itself of its patriarchal tendencies is unfathomable. It deprives a great number of victims of nontraditional sexual assaults of appropriate legal redress simply because the law refuses to recognize their perpetrators. The idea of the universality of human rights does not permit such an indefinite deference. Instead, the introduction of gender neutrality ought to be supplemented by simultaneous rape law and institutional reforms that focus on procedural safeguards to protect victims during rape trials, guidelines on sentencing, etc.

As a way forward, in order to address the gender-based power differentia in Indian society, the State may consider enacting differential evidentiary standards for those cases where the accused is a man. Likewise, to quell the potential threat of a countercomplaint by a man accused of raping a woman, the state may introduce certain penal consequences only in case a mala fide or frivolous complaint of rape is filed by a man. Each such measure, corroborated with appropriate judicial training, would constitute steps in the right direction, without resorting to deliberate underinclusion in the framing of its criminal laws. After all, the purpose of gender neutrality is not to eliminate the construct of gender from rape law jurisprudence, but only limit its influence in identifying the victims and perpetrators of rape. Therefore, with regard to the perpetrator, I believe the offence of rape under the IPC must be redrafted in gender-neutral terms.

As an imperfect alternative to complete gender neutrality, however, the state may at least consider enacting a separate gender-neutral offence of sexual assault of like seriousness, with identical punishments as those prescribed for committing the offence of rape. The suggestion is premised on the view that each distinct class of sexual assault victims, from women and children to sexual minorities, must be addressed separately. This way, while the offence of rape will remain limited to the traditional male-onfemale paradigm, the class of victims presently omitted from the criminal justice system will have some legal redress. While the reluctance to see nontraditional sexual assaults as an act of rape may deprive certain victims of the moral condemnation they warrant, many gender nonconformists would willingly consider it as yet another sacrifice by them in the larger interest of preserving human rights. After all, the "best" must never become the enemy of "good". ${ }^{186}$

\footnotetext{
I 85. See PLD, “Feminist Law Archives: Justice Verma Committee 20I3", online: PLD <http:// feministlawarchives.pldindia.org/category/sexual-violence/justice-verma-committee/>.

I 86. I am indebted to Professor Babu Mathew, erstwhile Professor at the National Law University - Delhi for this pithy observation.
} 